\title{
Emerging Scholar Award
}

\section{Catherine Butler ${ }^{1}$}

Accepted: 21 October 2020 / Published online: 29 October 2020

(c) Springer Nature B.V. 2020

During its long history, Children's Literature in Education has often benefitted from the refreshing ideas and original approaches of new scholars in the field of children's literature. In the current academic climate, the Humanities are under financial pressure in various countries. The competition for (post)doctoral scholarships is keen and tenured positions are becoming rare. In recognition of this, in 2013 CLE, with the support of its publisher, Springer, launched the annual Children's Literature in Education Emerging Scholar Award.

Each year, the winner of this prestigious award receives a prize of $\$ 500$ and their article is published in Children's Literature in Education, with an appropriate acknowledgement of its award-winning status. Excellent essays that do not win the award are still considered for publication in the journal.

The Editors congratulate Cathy Yue Wang, now of Shanghai Normal University, winner of Children's Literature in Education's 2019 Emerging Scholar Award. Her article, "Disappearing Fairies and Ghosts Female and Child Characters as Others in Chinese Contemporary Children's Fantasy," is published in this edition.

Time is almost up for entries for the 2020 award (they must be received by the end of the year), but we would like to take this opportunity to announce the 2021 award.

Applicants must submit an essay of 6000-8000 words to the Children's Literature in Education website (https://www.springer.com/journal/10583) before 31 December 2021.

Submission instructions can be found there, together with a guide to the journal's house style. All submitted articles must conform to this house style. When submitting your article, please select "Emerging Scholar Award" rather than "Standard Article."

Submissions must be original works that have not been published previously (including in conference proceedings) and that are not currently under consideration with another journal or edited collection.

To be eligible for this award, an Emerging Scholar is defined as someone who meets both the following criteria:

Catherine Butler

cathcbutler@gmail.com

1 Bristol, UK 
- has not defended a Ph.D. before 31 December 2018.

- has not published books, chapters or peer-reviewed articles on children's literature before 31 December 2016.

Submissions should be accompanied by a brief note indicating that the article is to be considered for the Emerging Scholar Award and affirming that the author meets these criteria.

Publisher's Note Springer Nature remains neutral with regard to jurisdictional claims in published maps and institutional affiliations. 